\title{
Comparative analysis of organic and elemental carbon concentrations in carbonaceous aerosols in three European cities
}

\author{
M. Viana \\ W. Maenhaut \\ H.M. ten Brink \\ X. Chi \\ E. Weijers \\ X. Querol \\ A. Alastuey \\ P. Mikuška \\ Z. Večeřa
}




\title{
Comparative analysis of organic and elemental carbon concentrations in carbonaceous aerosols in three European cities
}

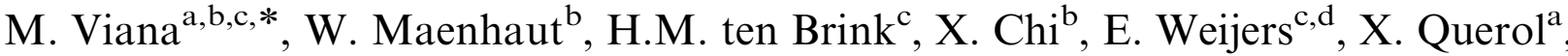 \\ A. Alastuey ${ }^{\mathrm{a}}, \mathrm{P}$. Mikuška ${ }^{\mathrm{e}}, \mathrm{Z}$. Večeřa ${ }^{\mathrm{e}}$ \\ anstitute of Earth Sciences "Jaume Almera”, C/ Lluís Solé I Sabarís s/n, 08028 Barcelona, Spain \\ ${ }^{\mathrm{b}}$ Institute for Nuclear Sciences (INW), Ghent University, Proeftuinstraat 86, 9000 Ghent, Belgium \\ ${ }^{\mathrm{c}}$ Energy Research Centre of the Netherlands (ECN), P.O. Box 1, 1755 ZG Petten, The Netherlands \\ ${ }^{\mathrm{d}}$ Municipal Health Institute Amsterdam (GGD), P.O. Box 2200, 1000CE Amsterdam, The Netherlands \\ ${ }^{\mathrm{e}}$ Institute of Analytical Chemistry, Academy of Sciences of the Czech Republic, Veveri 97, 60200 Brno, Czech Republic
}

Received 9 October 2006; received in revised form 7 March 2007; accepted 13 March 2007

\begin{abstract}
Sampling and analysis of carbonaceous compounds in particulate matter presents a number of difficulties related to artefacts during sampling and to the distinction between organic (OC) and elemental carbon (EC) during analysis. Our study reports on a comparative analysis of OC, EC and WSOC (water-soluble organic carbon) concentrations, as well as sampling artefacts, for PM2.5 aerosol in three European cities (Amsterdam, Barcelona and Ghent) representing Southern and Western European urban environments. Comparability of results was ensured by using a single system for sample analysis from the different sites. OC and EC concentrations were higher in the vicinity of roads, thus having higher levels in Amsterdam (3.9-6.7 and 1.7-1.9 $\mathrm{g} \mathrm{m}^{-3}$, respectively) and Barcelona (3.6-6.9 and 1.5-2.6 $\mu \mathrm{g} \mathrm{m}^{-3}$ ) than in Ghent $(2.7-5.4$ and $0.8-1.2 \mu \mathrm{g} \mathrm{m}^{-3}$ ). A relatively larger influence of secondary organic aerosols (SOA), as deduced from a larger OC/EC ratio, was observed in Ghent. In absolute sense, WSOC concentrations were similar at the three sites $\left(1.0-2.3 \mu \mathrm{g} \mathrm{m}^{-3}\right)$. Positive artefacts were higher in Southern (11-16\% of the OC concentration in Barcelona) than in Western Europe (5-12\% in Amsterdam, 5-7\% in Ghent). During special episodes, the contribution of carbonaceous aerosols from nonlocal sources accounted for $67-69 \%$ of the OC concentration in Western Europe, and for $44 \%$ in Southern Europe.

(C) 2007 Elsevier Ltd. All rights reserved.
\end{abstract}

Keywords: Sampling artefacts; Denuder; Urban aerosols; Secondary organic carbon

\section{Introduction}

Sampling and analysis of carbonaceous compounds in atmospheric particulate matter (PM)

\footnotetext{
*Corresponding author. Institute of Earth Sciences "Jaume Almera", C/ Lluís Solé I Sabarís s/n, 08028 Barcelona, Spain.

E-mail address: mviana@ija.csic.es (M. Viana).
}

present a number of difficulties derived from the large number and chemical variability of these compounds, as well as from the fact that most of them are semi-volatile (EPA, 1994). Furthermore, there is no reference analytical method for making a distinction between elemental (EC) and organic (OC) carbon (Salma et al., 2004). The results from an intercomparison of analysis methods for OC and 
EC (Schmid et al., 2001) show differences up to a factor of three. These are the main reasons why, despite the likely large contribution to the fine aerosol concentration (20-80\% of PM2.5, Nunes and Pio, 1993) and their adverse effects on human health (WHO, 2003), there is currently no EU-wide reference method for quantitative determination of the carbonaceous content of aerosols.

In particular, sampling of organic material on quartz fibre filters (EU reference method for PM) is subject to the adsorption of organic vapours and the loss of semi-volatile carbonaceous compounds, which result in the over- or underestimation of the carbon concentration in carbonaceous aerosols at the time of sampling. These artefacts are known as positive (adsorption) or negative (loss by volatilisation), and a number of authors have demonstrated the general prevalence of positive over negative artefacts (e.g., Turpin et al., 2000; Mader et al., 2001). Artefacts may be prevented or at least quantified by deploying different types of sampling setups such as those described by Mader et al. (2003), which include diffusion denuders to remove gaseous OC from the sample air-stream and the use of filters in series, impregnated or not by different adsorbents. The incidence and magnitude of the artefacts is greatly dependent on sampling conditions (meteorological variables such as temperature), sampling location (ambient concentrations of volatile organic compounds (VOCs) and sources of particulate carbon) and sample storage.

This research paper compiles the results from the sampling and determination of carbonaceous aerosols in three European cities (Amsterdam, Barcelona and Ghent), which are representative of Southern and Western European urban environments. Our main goals are to compare the levels of the different carbon fractions (OC, EC and water-soluble organic carbon (WSOC)) at the three sites, as well as to evaluate the incidence and magnitude of sampling artefacts as a function of sampling location and season (winter vs. summer). Finally, we attempt to discern the sources of organic species through the evaluation of the daily $\mathrm{OC} / \mathrm{EC}$ ratio coupled with back-trajectory analysis.

\section{Methodology}

\subsection{Study areas}

Two sampling campaigns (winter and summer) with a duration of approximately 5 weeks each were carried out at each of the sampling sites. The exact dates were 10/06/04-16/07/04 and 10/01/05-14/02/ 05 in Ghent (65 valid samples), 27/07/04-31/08/04 and $16 / 11 / 04-16 / 12 / 04$ in Barcelona (63 valid samples), and 04/07/05-02/08/05 and 09/01/06-16/ 02/06 in Amsterdam (62 valid samples). Even though the sampling campaigns were not simultaneous, a meteorological analysis of each of the sampling periods compared with the last 100 years demonstrated that the study periods may be considered as mostly representative of the different regions and seasons. Only the Amsterdam winter campaign was not wholly representative, given that high-pressure systems were dominant and it was one of the driest January months since 1901 . The study sites were:

- Amsterdam (742,951 inhabitants, The Netherlands, $\left.52^{\circ} 22^{\prime} \mathrm{N}, 4^{\circ} 54^{\prime} \mathrm{E}\right)$ : the sampling site was located at an approximate distance of $5 \mathrm{~m}$ from one of the major highways of the city (A10 ringroad), in an air quality monitoring cabin belonging to the GGD Amsterdam (Air Quality Monitoring Network). The instruments were located on the roof of the cabin, at 2-3 $\mathrm{m}$ above street level. The site was considered a traffic site. However, and in view of the comparison with the Barcelona and Ghent urban background sites, it is necessary to note that the daily PM2.5 mass concentration at the Amsterdam site showed a high correlation with data obtained from a nearby urban background station (Overtoom, $\left.r^{2}=0.86\right)$ and that the ratio for PM2.5 mass concentration of traffic/urban background was 1.1-1.2 during the study period. This similarity between PM2.5 mass concentrations at urban background and traffic sites in Amsterdam is also reflected in a report by the Dutch Milieu en Natuur Planbureau (http://www.mnp.nl/nl/publicaties/ 2005/fijn_stof_nader_bekeken.html, only available in Dutch).

- Barcelona (1,508,805 inhabitants, Spain, $\left.41^{\circ} 23^{\prime} \mathrm{N}, 2^{\circ} 11^{\prime} \mathrm{E}\right)$ : the monitoring station was located at an urban background site in the vicinity of an area with high traffic emissions, on the roof of the 2-storey building of the Institute of Earth Sciences "Jaume Almera". The institute is located within the University campus at approximately $150 \mathrm{~m}$ distance from one of the city's main traffic avenues, the Diagonal Avenue.

- Ghent (220,000 inhabitants, Belgium, $51^{\circ} 03^{\prime} \mathrm{N}$, $03^{\circ} 43^{\prime} \mathrm{E}$ ): the monitoring station was set at an 
urban background site on the roof of the Institute for Nuclear Sciences, a three-storey building located in the outskirts of the city and under the influence of the E17 and E40 motorways.

Daily mean minimum and maximum temperatures were 20 and $30^{\circ} \mathrm{C}$ in summer and 9 and $14{ }^{\circ} \mathrm{C}$ in winter in Barcelona, 11 and $20^{\circ} \mathrm{C}$ in summer and 2 and $7{ }^{\circ} \mathrm{C}$ in winter in Ghent, and 14 and $21^{\circ} \mathrm{C}$ in summer and 1 and $6{ }^{\circ} \mathrm{C}$ in winter in Amsterdam.

\subsection{Sampling instrumentation and methods}

The same sampling instruments were deployed at all three sites, and the analyses were performed at the same laboratories, with the analyses for the PM mass concentration, OC, EC and WSOC concentrations done at Ghent University. The following instrumentation was used:

- A low-volume PM2.5 sampler (16.7 $\mathrm{L} \mathrm{min}^{-1}$ ) with a stacked filter holder with two $47 \mathrm{~mm}$ quartz fibre filters in series (Whatman QM-A, filters Q1 and Q2). The front filter (Q1) collects $100 \%$ of the PM. The backup filter in this undenuded low-volume sampler (Q2) allows to assess the amount of gaseous species adsorbed on the sampling filter Q1. Detailed descriptions of this sampling setup and its possible limitations are given in Turpin et al. (2000) and Mader et al. (2001).

- A low-volume PM2.5 sampler $\left(16.7 \mathrm{~L} \mathrm{~min}^{-1}\right)$ with a stacked filter holder with two $47 \mathrm{~mm}$ quartz fibre filters in series (Whatman QM-A, filters DQ1 and DQ2), preceded by an annular diffusion denuder developed at the Institute of Analytical Chemistry, Czech Republic (Mikuška et al., 2003). A more detailed description of the denuder may be found in Viana et al. (2006a). Material found on the backup filter in the denuded low-volume sampler (DQ2) would result from: (a) the presence of negative artefacts (volatilisation of organic compounds from the front filter); (b) adsorption of volatile inorganic compounds (e.g., $\mathrm{HNO}_{3}$ ), or (c) the fact that the collection efficiency of the denuder for some gasphase organic compounds is $<100 \%$.

Apart from the low-volume samplers, a highvolume PM2.5 MCV sampler (Collbató, Spain, $500 \mathrm{~L} \mathrm{~min}^{-1}$ ) was also used with a filter holder for a single $15 \mathrm{~cm}$ diameter quartz fibre filter (Schleicher \& Schuell QF20).

All filters were pre-fired at $550{ }^{\circ} \mathrm{C}$ overnight before use, and stored in Millipore Petrislide dishes or baked aluminium foil. Samples were collected on a daily basis over $24 \mathrm{~h}$ (including weekends) with nominal start time at 9-10 a.m. (local time). After collection, the samples were stored in the freezer (mostly at $-25^{\circ} \mathrm{C}$ ) and they were also kept frozen during transport. PM mass was determined by weighing at $20{ }^{\circ} \mathrm{C}$ and $50 \%$ relative humidity with a Mettler MT5 microbalance ( $1 \mu \mathrm{g}$ sensitivity), after the filters (samples and blanks) had acclimatised for at least $24 \mathrm{~h}$. The filters were then analysed for OC and EC by a thermal-optical transmission (TOT) technique (Birch and Cary, 1996) using a Sunset Laboratory OCEC Analyser with a temperature programme described in Schmid et al. (2001), i.e., multistep temperature programme; $\mathrm{CO}_{2}-\mathrm{CH}_{4}-\mathrm{FID}$; OC: $900{ }^{\circ} \mathrm{C} \mathrm{He}, \mathrm{EC}: 900{ }^{\circ} \mathrm{C} \mathrm{O}_{2} / \mathrm{He}$. Total carbon (TC) was determined as the sum of OC + EC. OC, $\mathrm{EC}$ and TC values in this paper are given only for the undenuded low-volume sampler; results from the denuded low-volume sampler are used for the evaluation of artefacts. High-volume filters were used for the determination of WSOC using a Shimadzu TOC-V CPH high-sensitivity total organic carbon analyzer (details in Viana et al., 2006a). Concentrations of EC, OC, TC and WSOC throughout this paper are given as $\mu \mathrm{g} \mathrm{C} \mathrm{m}^{-3}$.

A detailed description of the uncertainties associated with the PM mass concentration and OC/EC/ TC measurements is given in Viana et al. (2006b). The average uncertainty of the mass determination for the filter samples is estimated as $1.4 \mu \mathrm{g} \mathrm{m}^{-3}$ for the low-volume samplers. The uncertainty for the OC/EC/TC analyses was around $0.2 \mu \mathrm{g} \mathrm{m}^{-3}$ for OC, $0.1 \mu \mathrm{g} \mathrm{m}^{-3}$ for EC and $0.3 \mu \mathrm{g} \mathrm{m}^{-3}$ for TC.

Analysis of air mass transport towards the study areas was performed using Hysplit v.4 (Draxler and Rolph, 2003), by calculation of 5-day isentropic back-trajectories at 1500,750 and $500 \mathrm{~m}$ a.g.l.

\section{Results and discussion}

\subsection{OC/EC/WSOC concentrations}

The mean concentrations of the carbon fractions analysed for each season and each site are given in Table 1, together with the mean PM2.5 mass concentration. The distribution of the $\mathrm{OC}$ and $\mathrm{EC}$ daily data (mean, maximum, minimum and $25 \%$ 
Table 1

Mean PM2.5 mass, OC, EC, TC and WSOC concentrations (and associated standard deviations in parentheses) obtained with the undenuded low-volume sampler (except for WSOC, which is derived from the high-volume filters) at the three sites during the summer and winter sampling campaigns

\begin{tabular}{|c|c|c|c|c|c|c|c|c|}
\hline & $\begin{array}{l}\text { PM2.5 mass } \\
\left(\mu \mathrm{g} \mathrm{m}^{-3}\right)\end{array}$ & $\begin{array}{l}\mathrm{OC} \\
\left(\mu \mathrm{g} \mathrm{m}^{-3}\right)\end{array}$ & $\begin{array}{l}\mathrm{EC} \\
\left(\mu \mathrm{g} \mathrm{m}^{-3}\right)\end{array}$ & $\begin{array}{l}\mathrm{TC} \\
\left(\mu \mathrm{g} \mathrm{m}^{-3}\right)\end{array}$ & $\begin{array}{l}\text { WSOC } \\
\left(\mu \mathrm{g} \mathrm{m}^{-3}\right)\end{array}$ & $\mathrm{OC} / \mathrm{EC}$ & $\mathrm{EC} / \mathrm{TC}$ & $\begin{array}{l}\text { WSOC/ } \\
\text { OC }\end{array}$ \\
\hline \multicolumn{9}{|l|}{ Winter } \\
\hline Amsterdam & $34.4(15.8)$ & $6.7(3.8)$ & $1.7(0.9)$ & $8.4(4.1)$ & $1.9(1.5)$ & 4.7 & 0.22 & 0.34 \\
\hline Barcelona & $29.1(15.3)$ & $6.9(2.5)$ & $2.6(1.4)$ & $9.5(3.7)$ & $2.1(0.8)$ & 3.1 & 0.27 & 0.33 \\
\hline Ghent & $20.8(18.3)$ & $5.4(4.5)$ & $1.2(0.6)$ & $6.6(4.9)$ & $2.3(2.2)$ & 4.4 & 0.23 & 0.40 \\
\hline \multicolumn{9}{|l|}{ Summer } \\
\hline Amsterdam & $17.8(7.8)$ & $3.9(1.6)$ & $1.9(0.7)$ & $5.8(2.0)$ & $1.0(0.6)$ & 2.8 & 0.33 & 0.34 \\
\hline Barcelona & $17.7(6.0)$ & $3.6(1.4)$ & $1.5(0.7)$ & $5.1(2.0)$ & $1.6(0.7)$ & 2.6 & 0.28 & 0.43 \\
\hline Ghent & $15.7(4.9)$ & $2.7(1.0)$ & $0.8(0.3)$ & $3.5(1.2)$ & $1.0(0.4)$ & 3.5 & 0.24 & 0.42 \\
\hline
\end{tabular}

OC/EC, EC/TC and WSOC/OC ratios calculated on a sample-by-sample basis and subsequently averaged over all samples of the campaign. OC data are uncorrected for positive artefacts.

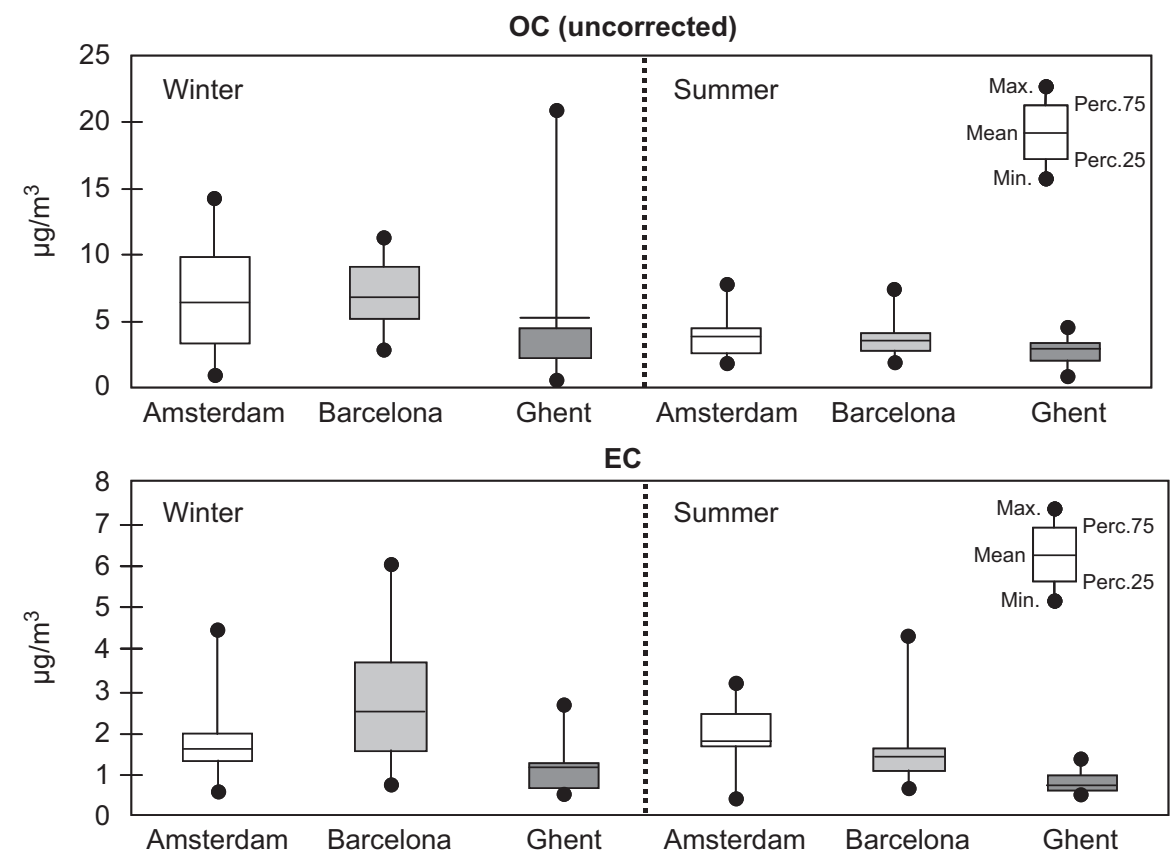

Fig. 1. Mean, maximum and minimum OC (uncorrected) and EC concentrations, as well as percentiles $75 \%$ and $25 \%$, obtained in Amsterdam, Barcelona and Ghent during the winter and summer sampling campaigns.

and $75 \%$ percentiles) is shown in Fig. 1. According to these results, during the winter campaign PM2.5 mass mean concentrations were the highest in Amsterdam $\left(34.4 \mu \mathrm{g} \mathrm{m}^{-3}\right)$, followed by Barcelona $\left(29.1 \mu \mathrm{g} \mathrm{m}^{-3}\right)$ and Ghent $\left(20.8 \mu \mathrm{g} \mathrm{m}^{-3}\right)$. Conversely, in summer PM2.5 mass mean concentrations were very similar in Barcelona and Amsterdam (17.7 and $17.8 \mathrm{\mu g} \mathrm{m}^{-3}$, respectively) and still higher than in Ghent $\left(15.7 \mu \mathrm{g} \mathrm{m}^{-3}\right)$. In the case of Barcelona, the mean of the summer and winter values is close to the annual mean obtained for 2004 at the same monitoring site by Querol et al. (unpublished data, mean PM2.5 mass concentration $=25 \mu \mathrm{g} \mathrm{m}^{-3}$ ). As regards Amsterdam, our winter mean is higher than that given by Sillanpää et al. (2005) for a winter campaign in Amsterdam (January-March 2003, $25.4 \mu^{-3} \mathrm{~m}^{-3}$ ). The higher concentrations registered in Amsterdam could be related with a strong pollution episode registered in January-February 2006, which extended from Western to Central 
Europe. Finally, PM2.5 mass concentrations in Ghent in our study are slightly higher than those presented by Maenhaut et al. (2003) for a summer campaign in 2002 (median value $12.4 \mu \mathrm{g} \mathrm{m}^{-3}$ ).

\subsection{1. $O C$}

OC concentrations presented in Table 1 and Fig. 1 are the raw data from the front filters from the undenuded sampler (Q1), uncorrected for the OC concentration on the backup filters (Q2, Maenhaut et al., 2004, 2005; Viana et al., 2006b). These data were used instead of the corrected ones (from now on referred to with the subindex "c" for "corrected") due to the fact that the assumptions made by Mader et al. (2003) in order to allow one to apply the correction did not seem to be valid at all sites during all campaigns, as discussed below, in particular not for the Ghent 2004 summer campaign (Maenhaut et al., 2005). Therefore, we have chosen to present here the uncorrected front filter data and to evaluate separately the possible artefacts.

Mean OC concentrations in Amsterdam and Barcelona are very similar during winter and summer (3.6-3.9 $\mu \mathrm{g} \mathrm{m}^{-3}$ in summer, 6.7-6.9 $\mu \mathrm{g} \mathrm{m}^{-3}$ in winter), and they are higher than the mean OC concentrations in Ghent by approximately a factor of $1.3-1.4\left(2.7 \mu \mathrm{g} \mathrm{m}^{-3}\right.$ in summer, $5.4 \mu \mathrm{g} \mathrm{m}^{-3}$ in winter). These results show that the OC concentrations are strongly influenced by local sources, as the concentrations are substantially different at the two Western European sites. Mean OC concentrations in winter are higher than these in summer by a factor of 1.7 for Amsterdam, 1.9 for Barcelona and 2.0 for Ghent, mostly as a consequence of lower dispersive atmospheric conditions in winter. However, if this were the only cause for the OC winter increase then the same factors would be expected for EC, but they are actually lower (1.5-1.7, at all sites). Therefore, it is concluded that additional sources must contribute to the elevated OC concentrations in winter, possibly in the form of biomass burning or household heating systems. The variability in the OC concentrations is also substantially higher in winter than in summer (Fig. 1). This could be related to the larger contribution in summer of regional-scale secondary organic aerosols (SOA) which results in relatively homogeneous concentrations, whereas local contributions with a stronger daily variability prevail in winter. It is interesting to note that in the case of Amsterdam, the mean OC

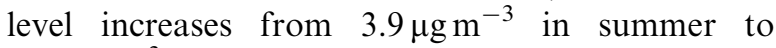
$6.7 \mu \mathrm{g} \mathrm{m}^{-3}$ in winter, whereas the mean EC level remains constant and even decreases slightly $\left(1.9 \mu \mathrm{g} \mathrm{m}^{-3}\right.$ in summer vs. $1.7 \mu \mathrm{g} \mathrm{m}^{-3}$ in winter).

\subsection{2. $E C$}

At Barcelona, the highest mean EC level is observed in winter $\left(2.6 \mu \mathrm{g} \mathrm{m}^{-3}\right)$, whereas at Amsterdam it occurs in summer $\left(1.9 \mu \mathrm{g} \mathrm{m}^{-3}\right)$, and at Ghent the mean EC concentrations are low during both seasons $\left(0.8 \mu \mathrm{g} \mathrm{m}^{-3}\right.$ in summer, $1.2 \mu \mathrm{g} \mathrm{m}^{-3}$ in winter, Table 1). If EC concentrations are considered tracers of primary emissions mostly derived from traffic (Turpin and Huntzicker, 1995; Salma et al., 2004), these results suggest that the influence of traffic is lower at the Ghent site than in Amsterdam and Barcelona. Furthermore, they would also indicate that the influence of traffic emissions is similar at the urban background site in Barcelona and the traffic site in Amsterdam. The mean EC/TC ratios varied from 0.22 to 0.27 in winter and from 0.24 to 0.33 in summer, reaching the highest values in Amsterdam in summer and showing a clear increase from winter to summer. This increase could be related to wood burning emissions with low EC/ TC ratios in winter, as observed in Ghent by Zdráhal et al. (2002). However, wood burning in the Amsterdam region is considered to be relatively scarce, even during wintertime.

\subsubsection{WSOC}

Mean WSOC concentrations are relatively similar at the three sites in the respective seasons $\left(1.0-1.6 \mu \mathrm{g} \mathrm{m}^{-3}\right.$ in summer, $1.9-2.3 \mu \mathrm{g} \mathrm{m}^{-3}$ in winter), showing an increase in the WSOC/OC ratios towards the summer in Barcelona (33-43\%). This increase may be due to enhanced photochemical oxidation forming oxygen containing functional groups which increase water solubility in summer, as well as to enhanced wet depositional losses of WSOC relative to the insoluble carbon in winter (Kleefeld et al., 2002). The increase is negligible in Ghent (from $40 \%$ to $42 \%$ ) and is not observed at all in Amsterdam (34\% in summer and winter), probably due to the lower seasonal contrast characteristic of the Western European regions when compared to the South.

As a result, the mean concentrations of most of the parameters evaluated so far (PM2.5 mass, OC, EC) seem to show a much stronger dependence on local sources than on the sampling location (Western vs. Southern Europe), with only the seasonal trend of WSOC in Amsterdam showing a dependence on meteorological conditions. Cities 
like Amsterdam and Barcelona show relatively similar concentrations of OC and EC, while Ghent shows lower OC and EC concentrations and higher WSOC/OC ratio. These differences could indicate a larger influence of SOA in Ghent and a stronger traffic signal in Amsterdam and Barcelona. It is also interesting to note that among our sites even the station type does not seem to have an influence on the concentrations of the parameters measured, considering that similar results were obtained at Amsterdam (traffic) and Barcelona (urban background, although of an area with high traffic emissions). In Amsterdam the fine aerosol concentrations are, however, relatively homogeneous at different urban stations, with only minor influence of their location in background or kerbside environments (as described above). This specific characteristic is probably a result of the combination of strongly dispersive conditions throughout the year (dominant advection of Atlantic air masses) and a mostly flat topography favouring pollutant dispersion in Amsterdam. In Barcelona, urban topography is a probable cause of the accumulation of pollutants in the near proximity to the emission sources and the consequent heterogeneity in the OC and EC concentrations at the different station types, given the high buildings and narrower street canyons. PM2.5 mass concentrations recorded at traffic sites in Barcelona are $5-10 \mu \mathrm{g} \mathrm{m}^{-3}$ higher than at urban background sites (Querol et al., 2004).

\subsection{Sampling artefacts}

The sampling artefacts for $\mathrm{OC}$ were quantified from the OC data for the front and backup filters of the denuded and undenuded samples following the approach of Mader et al. (2003), with $\mathrm{Q} 1_{\mathrm{c}}=\mathrm{Q} 1-\mathrm{Q} 2$ and $\mathrm{DQ} 1_{\mathrm{c}}=\mathrm{DQ} 1+\mathrm{DQ} 2$. According to these authors, this approach is only valid if positive artefacts prevail for the front filters in the undenuded samples and negative artefacts prevail for the front filters in the denuded samples. Negative artefacts for $\mathrm{OC}$ in de undenuded sampling may have existed at the three sites, especially in Barcelona during the summer months, but they are estimated to be minor in comparison to positive artefacts (Turpin et al., 2000; Mader et al., 2001). Various ratios for assessing the impact of the artefacts are given in Table 2.

Before interpreting the data on artefacts it was necessary to verify the efficiency of the experimental setup. The efficiency of the denuder may be tested
Table 2

Ratios between front and backup, denuded and undenuded filter samples for OC and EC concentrations during the summer and winter sampling periods at the three study sites

\begin{tabular}{lrlr}
\hline & Amsterdam & Barcelona & Ghent \\
\hline Winter & & & \\
Q2/Q1 1 (OC) & 0.05 & 0.11 & 0.07 \\
DQ1/Q1 (EC) & 1.05 & 0.95 & 1.08 \\
DQ2/DQ1 $($ OC) & -0.01 & 0.10 & 0.03 \\
DQ1 /Q1 $($ OC) & 0.82 & 1.04 & 0.97 \\
Q2(OC)/PM2.5 mass & 0.01 & 0.03 & 0.01 \\
Summer & & & \\
Q2/Q1 1 (OC) & 0.12 & 0.16 & 0.05 \\
DQ1/Q1 (EC) & 0.94 & 0.90 & $1.17^{\mathrm{a}}$ \\
DQ2/DQ1 (OC) & 0.01 & 0.09 & -0.07 \\
DQ1 $/$ Q1 $(O C)$ & 0.94 & 1.10 & 0.70 \\
Q2(OC)/PM2.5 mass & 0.03 & 0.03 & 0.01 \\
\hline
\end{tabular}

OC data for the front filters are corrected for artefacts (see text for details). Ratios calculated on a sample-by-sample basis and subsequently averaged over all samples.

${ }^{a}$ Due to contamination by activated charcoal from the denuder in Ghent.

by calculating the ratio of $\mathrm{OC}$ on backup to front filters for the denuded samples (DQ2/DQ1 Table 2), which should be close to zero if the denuder retains $>99 \%$ of gaseous OC as stated by Mikuška et al. (2003) and if losses of semi-volatile OC from the front filter (negative artefacts) are negligible. The $\mathrm{DQ} 2 / \mathrm{DQ} 1_{\mathrm{c}}$ ratio ranged from -0.07 to 0.10 at all sites, thus indicating that the efficiency of the denuder system was high and negative artefacts were minimal. Even in the case of Barcelona (DQ2/DQ1 $=0.09-0.10)$, these results are within the uncertainty of the measurements (OC uncertainty $=0.2 \mu \mathrm{g} \mathrm{m}^{-3}$, mean OC on backup filters $=0.26-0.35 \mu \mathrm{g} \mathrm{m}^{-3}$ ).

The ratio DQ1/Q1 for EC also provides insight in the correct working of the setup, as EC should not be affected by positive or negative artefacts and thus this ratio should be close to 1 . This analysis allowed us to detect EC contamination during the Ghent summer campaign (DQ1/Q1 for $\mathrm{EC}=1.17)$, which was not observed in any of the other campaigns (DQ1/Q1 for $E C=0.90-1.08$ for the other five campaigns, Table 2). Consequently, EC concentrations derived from the denuded setup for the Ghent summer campaign are overestimated by contamination from the denuder (for details, see Viana et al., 2006b).

The magnitude of the OC adsorption on quartz fibre filters was quantified by calculating the backup 
to front filter ratio for $\mathrm{OC}$ in the undenuded samples $\left(\mathrm{Q} 2 / \mathrm{Q} 1_{\mathrm{c}}(\mathrm{OC})\right.$, Table 2). OC on the backup filters (thus originally in gaseous form) during winter accounted for $5 \%$ of the front filter $\mathrm{OC}$ in Amsterdam, 11\% in Barcelona and 7\% in Ghent. During the summer periods, these percentages were higher in Amsterdam and Barcelona $(12 \%$ and $16 \%$, respectively) and only slightly lower in Ghent $(5 \%)$. In absolute terms, undenuded OC concentrations may be overestimated by $0.3-0.5 \mu \mathrm{g} \mathrm{m}^{-3}$ in Amsterdam, by $0.5-0.7 \mu \mathrm{g} \mathrm{m}^{-3}$ in Barcelona, and by $0.2-0.3 \mu \mathrm{g} \mathrm{m}^{-3}$ in Ghent because of the adsorption of organic gases on Q1. These results suggest that whereas in Barcelona and Amsterdam positive artefacts for $\mathrm{OC}$ are higher during summer, in Ghent their influence is relatively constant during both seasons. Moreover, when comparing Amsterdam and Barcelona, the highest Q2/Q1 $(\mathrm{OC})$ ratios are consistently observed in the latter, probably as a result of higher average temperatures during both seasons and the enhanced emission of VOCs and the enhanced volatilisation of semi-volatile species. If we consider that these differences are due exclusively to regional characteristics (higher temperatures in Southern vs. Western Europe), then a similar seasonal dependence would be expected in Amsterdam and Ghent given their relative proximity. The lack of seasonal dependence in Ghent implies that the high $\mathrm{Q} 2 / \mathrm{Q} 1_{\mathrm{c}}$ summer ratio for $\mathrm{OC}$ in Amsterdam and Barcelona does not only derive from higher summer temperatures, but is also linked to differences in VOC sources and semi-volatile organic aerosol characteristics.

The impact of positive sampling artefacts for OC on the bulk PM2.5 mass concentration is expressed by the ratio Q2(OC)/PM2.5 mass (Table 2). During our sampling campaigns, undenuded PM2.5 mass concentrations may have been overestimated on average by $1-3 \%$ due to positive artefacts for OC at all sites and during both seasons, with daily maximum values of $14 \%$ in Amsterdam in summer, $8 \%$ in Barcelona in winter and $3 \%$ in Ghent during both seasons. On average, the excess mass from artefact $\mathrm{OC}$ is below the uncertainty of the gravimetric mass determination, and consequently does not have an impact on the application of the daily or annual limit values established by Directive EU/30/1999 (1999) for PM10. However, these results may be significant from an epidemiological or toxicological point of view.

Finally, if the assumptions for using the approach of Mader et al. (2003) are valid, then the corrected
OC data from the denuded and undenuded front filter samples should be the same (DQ1 $/ \mathrm{Q} 1_{\mathrm{c}}$ for $\mathrm{OC}$ close to 1$)$. The results in Table 2 show that the assumptions were valid within the uncertainty for Barcelona in winter and summer (1.04-1.10), for Amsterdam in summer (0.94) and for Ghent in winter (0.97). However, the OC correction did not provide satisfactory results in Ghent during summer $\left(\mathrm{DQ} 1_{\mathrm{c}} / \mathrm{Q} 1_{\mathrm{c}}=0.70\right)$ or Amsterdam in winter $(0.82)$.

\subsection{Sources of carbonaceous aerosols}

The variation in the OC/EC ratio may be used as an indicator of changes in emission sources, source processes or source regions, given that EC may be considered as a tracer for primary emissions of carbonaceous species (Turpin and Huntzicker, 1995; Salma et al., 2004). The uncorrected (undenuded) OC data were used for this analysis, as the assumptions for the correction according to Mader et al. (2003) proved not to be valid for all the sampling sites and periods.

Daily OC/EC ratios ranged between 0.9 and 15.3 in Amsterdam, 1.3 and 5.4 in Barcelona, and 1.4 and 12.9 in Ghent. Clearly, there is a larger dispersion in the $\mathrm{OC} / \mathrm{EC}$ ratios for Amsterdam and Ghent than for Barcelona, and higher maximum ratios (by a factor of 2-3) were obtained in Western (12.9-15.3) than in Southern Europe (5.4). The days with high OC/EC ratios, defined as those with OC/EC ratios higher than the $75 \%$ percentile (5.0 in Amsterdam, 3.5 in Barcelona, 5.1 in Ghent), were selected to analyse the possible sources of carbonaceous aerosols. These days showed OC/EC signals which differed markedly from the average values, thus implying that the sources of carbonaceous aerosols were also likely to be different from the most usual local sources.

Once the days for source analysis were selected, back-trajectory and OC and EC data were added to the analysis (Fig. 2). As a result, three groups of sampling days were observed for each site, as a function primarily of the OC/EC ratio, but also of back-trajectory analysis. These groups of sampling days were interpreted as three different types of PM episodes (Table 3 and Fig. 3):

(a) Continental episodes: Mean OC/EC ratios were 8.9, 4.2 and 8.9 in Amsterdam, Barcelona and Ghent, respectively, with high values mainly resulting from high OC concentrations. Carbonaceous aerosols during these days were, on average, not emitted by local sources, but had on the contrary a 
a

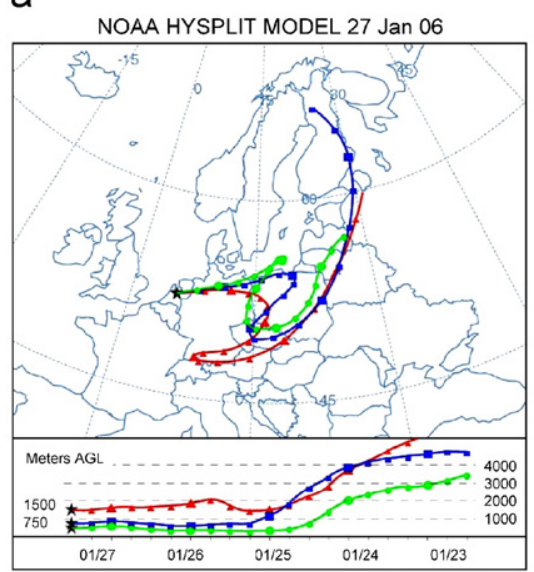

d

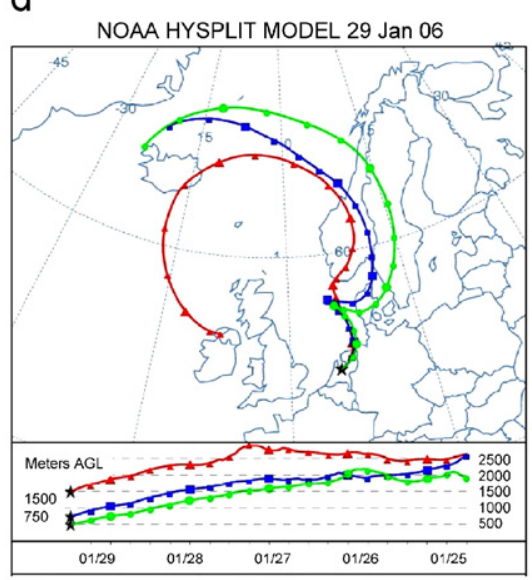

b

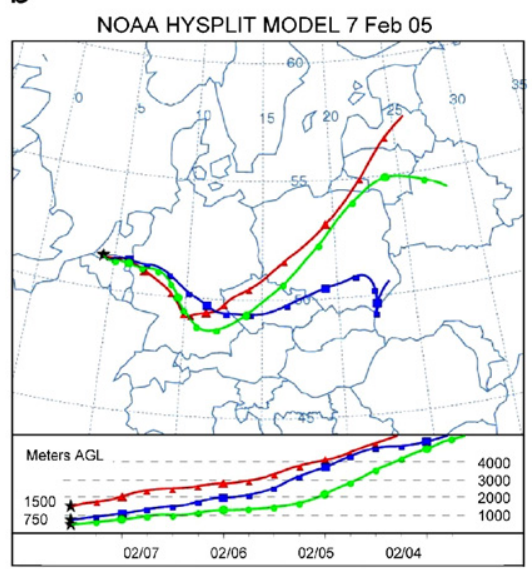

e

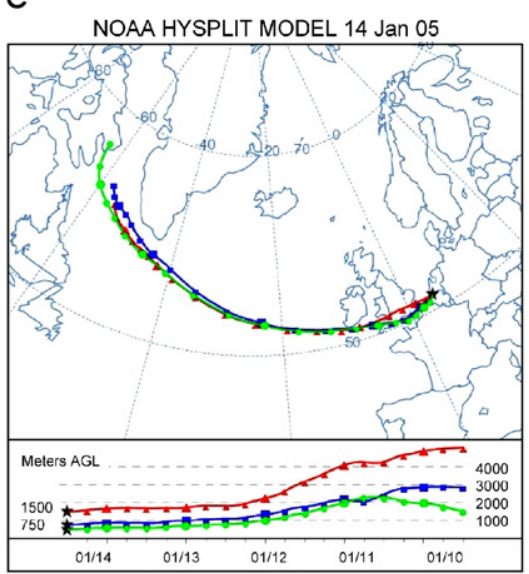

C

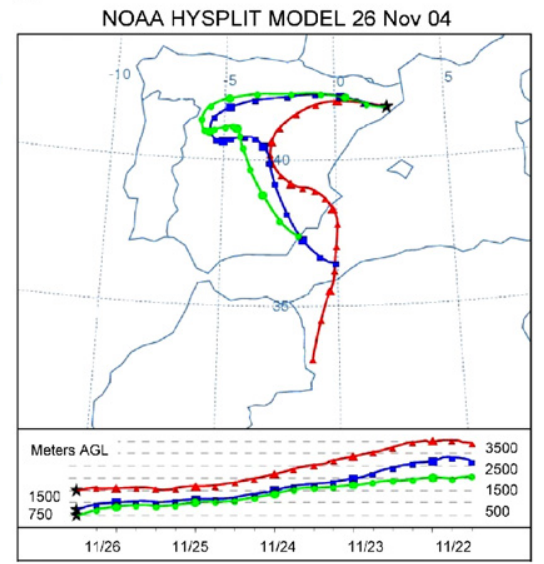

f

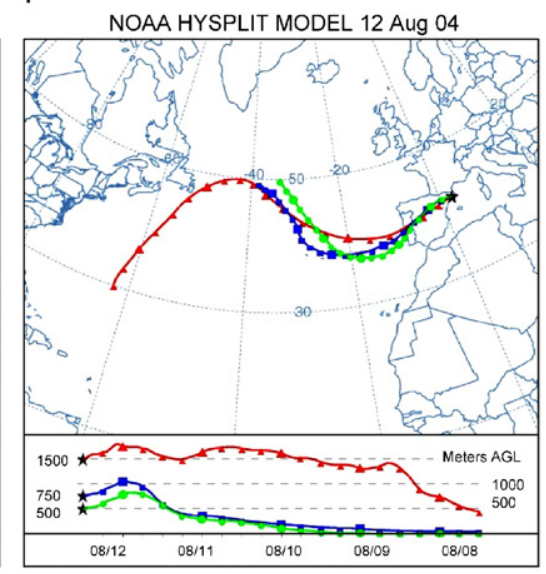

Fig. 2. Examples of the most frequent back-trajectories for continental and Atlantic episodes (described in the text). (a)-(c) represent examples of continental episodes in Amsterdam, Ghent and Barcelona, respectively. (d)-(f) represent examples of Atlantic episodes in Amsterdam, Ghent and Barcelona, respectively.

Table 3

Mean PM2.5 mass $\left(\mu \mathrm{g} \mathrm{m}^{-3}\right)$, OC $\left(\mu \mathrm{g} \mathrm{m}^{-3}\right), \mathrm{EC}\left(\mu \mathrm{g} \mathrm{m}^{-3}\right), \mathrm{OC} / \mathrm{EC}, \mathrm{EC} / \mathrm{TC}$ and WSOC/OC levels during the three types of carbonaceous aerosol episodes identified

\begin{tabular}{|c|c|c|c|c|c|c|c|c|c|c|}
\hline & Type & $N$ & Main traj. & $\begin{array}{l}\text { PM2.5 } \\
\text { mass }\end{array}$ & $\mathrm{OC}$ & $\mathrm{EC}$ & $\mathrm{OC} / \mathrm{EC}$ & $\mathrm{EC} / \mathrm{TC}$ & $\begin{array}{l}\text { WSOC/ } \\
\text { OC }\end{array}$ & $\% \mathrm{OC}$ external \\
\hline \multirow[t]{3}{*}{ Amsterdam } & Continental & 8 & EU & 52.2 & 11.7 & 1.4 & 8.9 & 0.11 & 0.34 & \multirow[t]{3}{*}{$69 \%\left(8.2 \mu \mathrm{g} \mathrm{m}^{-3}\right)$} \\
\hline & Atlantic & 6 & AT & 16.7 & 3.3 & 0.5 & 7.4 & 0.13 & 0.36 & \\
\hline & Local & 48 & $\mathrm{AT} / \mathrm{L}$ & 23.7 & 4.6 & 2.0 & 2.5 & 0.32 & 0.22 & \\
\hline \multirow[t]{3}{*}{ Barcelona } & Continental & 11 & REG & 32.4 & 7.0 & 1.7 & 4.2 & 0.19 & 0.36 & \multirow[t]{3}{*}{$44 \%\left(3.1 \mu \mathrm{g} \mathrm{m}^{-3}\right)$} \\
\hline & Atlantic & 6 & $\mathrm{AT} / \mathrm{MED}$ & 14.1 & 4.0 & 0.9 & 4.4 & 0.19 & 0.42 & \\
\hline & Local & 46 & $\mathrm{AT} / \mathrm{L}$ & 22.4 & 4.8 & 2.2 & 2.3 & 0.31 & 0.35 & \\
\hline \multirow[t]{3}{*}{ Ghent } & Continental & 6 & EU & 55.2 & 12.9 & 1.4 & 8.9 & 0.10 & 0.48 & \multirow[t]{3}{*}{$67 \%\left(8.9 \mu \mathrm{g} \mathrm{m}^{-3}\right)$} \\
\hline & Atlantic & 11 & AT & 19.9 & 4.0 & 0.6 & 6.6 & 0.14 & 0.40 & \\
\hline & Local & 46 & $\mathrm{AT} / \mathrm{L}$ & 17.3 & 3.1 & 1.1 & 2.8 & 0.28 & 0.42 & \\
\hline
\end{tabular}

OC data are uncorrected for positive artefacts. $N$ : no. of days. Main traj.: main type of back-trajectory, EU: European, AT: Atlantic, REG: regional, MED: Mediterranean, L: local, anticyclonic scenario. Ratios calculated on a sample-by-sample basis and subsequently averaged over all samples. \%OC external: \%OC non-local, i.e., originating from regional-scale circulations or long-range transport. 

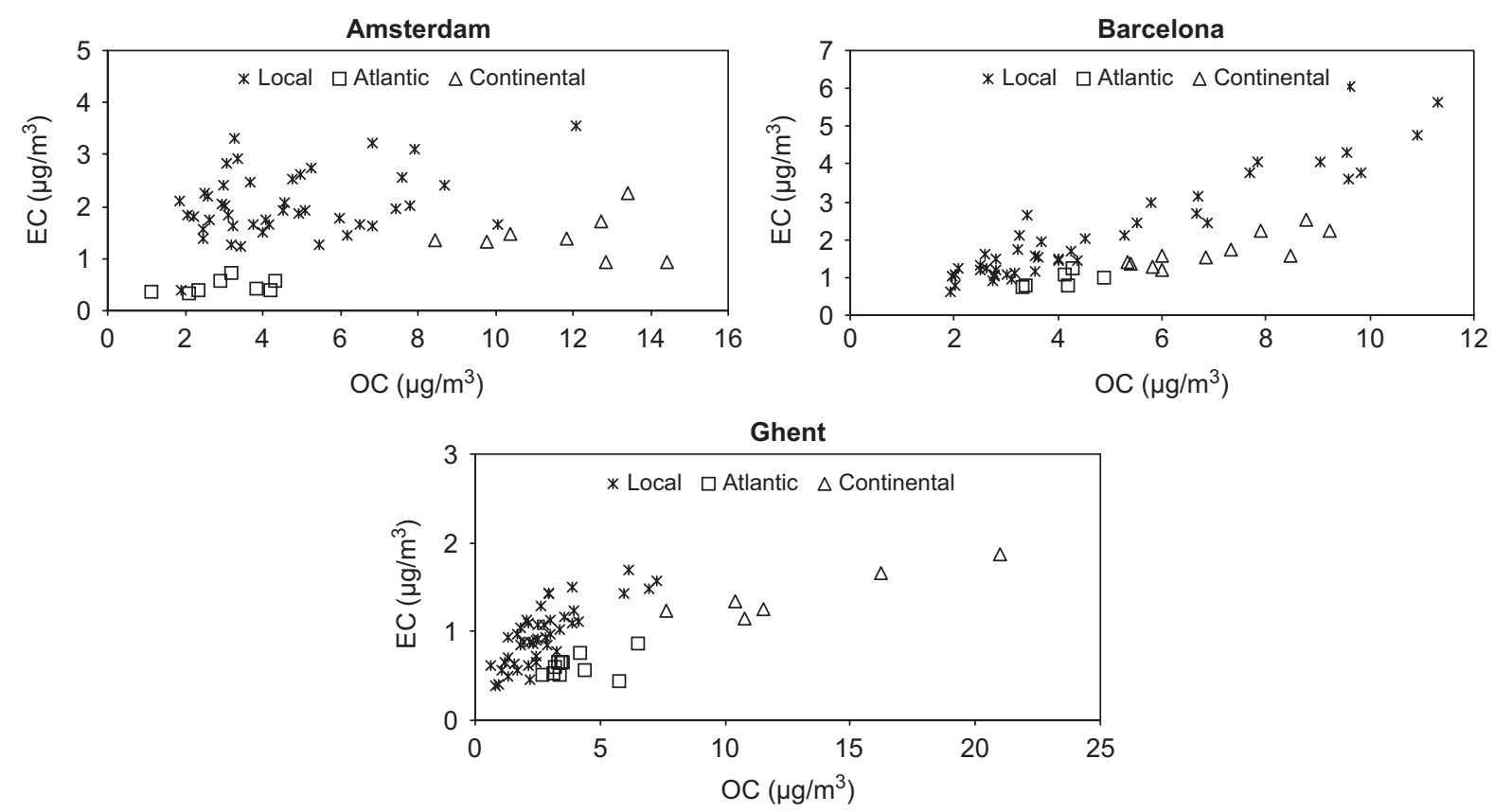

Fig. 3. Scatter plots of OC vs. EC concentrations $\left(\mu \mathrm{g} \mathrm{Cm}^{-3}\right)$ for Amsterdam, Barcelona and Ghent, as a function of the three types of PM episodes (continental, local and Atlantic) described.

regional or long-range continental European origin. Back-trajectory analysis showed that in the case of Amsterdam and Ghent, the origin of the air masses was mainly Southern and Eastern European (88\% of the days in Amsterdam, $67 \%$ of the days in Ghent, Fig. 2a and b). In the case of Barcelona, the air mass transport was over Europe on $27 \%$ of the days and on the regional-scale over the Eastern and Central Iberian Peninsula on $65 \%$ of the days (Fig. 2c). Especially high OC concentrations were noted at all sites $\left(7.0-12.9 \mu \mathrm{g} \mathrm{m}^{-3}\right.$, Table 3) with relatively low EC concentrations $\left(1.4-1.7 \mu \mathrm{g} \mathrm{m}^{-3}\right)$. Therefore, episodes defined as continental were characterised by high $\mathrm{OC} / \mathrm{EC}$ ratios resulting from high OC concentrations of secondary origin (SOA), due to long- or regional-scale air mass transport. In Amsterdam and Ghent all of the episodes were registered during the winter period, as was the case for $82 \%$ of the days (9 of 11) in Barcelona. Thus, the high $\mathrm{OC}$ concentrations registered are not likely to be caused by volatilisation due to high ambient temperatures.

As regards EC concentrations, Table 3 shows that the EC concentrations during continental episodes were similar to those during local episodes. Thus, it is possible to assume a common source for these EC levels, which would be local emissions. According to this assumption, the product of the mean EC concentrations during continental episodes and the mean $\mathrm{OC} / \mathrm{EC}$ ratio during local episodes would result in an estimate of the contribution of locally emitted OC. By difference with the total OC concentration, the non-local (externally produced) OC concentration may be estimated. As a result, during continental episodes in Amsterdam and Ghent $69 \%$ and $67 \%$ (respectively) of the OC concentration could have originated from longrange transport, with only $31-33 \%$ being emitted locally. On the other hand, in Barcelona $44 \%$ of the OC concentration would have been due to long- or regional-scale transport, while the remaining 56\% was emitted by local sources. It is also interesting to note that the PM2.5 mass concentration reached maximum values in Amsterdam and Ghent during these episodes (52.2 and $55.2 \mu \mathrm{g} \mathrm{m}^{-3}$, respectively), while in Barcelona PM2.5 mass concentrations were only $10 \mu \mathrm{g} \mathrm{m}^{-3}$ higher that during local episodes.

(b) Atlantic episodes: Mean OC/EC ratios were 7.4, 4.4 and 6.6 in Amsterdam, Barcelona and Ghent, respectively, with high values mainly resulting from low EC concentrations. These episodes were characterised by strong advection of clean Atlantic air masses at all sites (Fig. 2d and e), with resulting air mass renewal and markedly low EC 
concentrations $\left(0.5-0.9 \mu \mathrm{g} \mathrm{m}^{-3}\right.$, Table 3$)$. OC concentrations were also reduced during these days (60-90\% of the overall mean OC concentrations) although not as much as EC concentrations, probably because of the contribution of regionalscale SOA. PM2.5 mass concentrations were also the lowest during these days. This type of episode prevailed in summer in Amsterdam and Barcelona (4 of 6 days at each site, even though Atlantic episodes are not generally common in Barcelona in summer), while in Ghent the 11 days were spread rather homogeneously throughout both sampling periods ( 6 days in summer, 5 days in winter). The seasonality of these events does not suggest any dependence of the OC/EC ratios on meteorological conditions. The major characteristic of these episodes is the low EC concentrations recorded, which are more likely to be caused by the absence of EC sources in Atlantic source regions. Mean ambient temperatures during these days ranged from $14{ }^{\circ} \mathrm{C}$ in Amsterdam to $21^{\circ} \mathrm{C}$ in Barcelona.

(c) Local episodes: This group of days includes those excluded from the categories above, showing $\mathrm{OC} / \mathrm{EC}<75 \%$ percentile. Air mass transport during these days was from a variety of source regions, mostly Atlantic in Amsterdam and Ghent, and Atlantic and Mediterranean in Barcelona. However, their common characteristic was that anticyclonic scenarios favouring air mass stagnation dominated at least $40 \%$ of the days in Amsterdam and Ghent and $45 \%$ of the days in Barcelona. These days were found almost equally in summer and winter in Amsterdam and Ghent (47\% of the days in winter in Amsterdam, $52 \%$ in Ghent), and were relatively more frequent in summer in Barcelona ( $66 \%$ of the days). The origin of carbonaceous aerosols during these days was interpreted as mostly local, with traffic prevailing as the major source, although other sources such as biomass burning may also have been present, especially in winter in Western Europe. Mean OC and EC concentrations for the local episodes were similar to the overall mean concentrations for each site: during the local episodes mean OC concentrations were $3.1-4.8 \mu \mathrm{g} \mathrm{m}^{-3}$ (Table 3), and mean EC concentrations were $1.1-2.2 \mu \mathrm{g} \mathrm{m}^{-3}$. Also the mean PM2.5 mass concentrations during the episodes $\left(23.7 \mu \mathrm{g} \mathrm{m}^{-3}\right.$ in Amsterdam, $22.4 \mu \mathrm{g} \mathrm{m}^{-3}$ in Barcelona, $17.3 \mu \mathrm{g} \mathrm{m}^{-3}$ in Ghent) resembled the overall mean concentrations for each of the sites.

Finally, the WSOC/OC ratio was also evaluated for the three types of episodes identified. The WSOC/OC ratio showed a lower variation in
Barcelona and Ghent $(0.35-0.42$ and $0.40-0.48$, respectively) than in Amsterdam (0.23-0.36), but no significant regional or seasonal trends were detected.

\section{Summary and conclusions}

Concentrations of OC, EC, TC, WSOC for PM2.5 aerosol and PM2.5 mass concentrations were determined during summer and winter periods at three urban sites in Southern (Barcelona) and Western Europe (Amsterdam and Ghent). Our setup using the same instrumentation and laboratory for analysis ensured the comparability of the results, providing a solid base for the evaluation of regional differences between the concentrations and composition of carbonaceous aerosols in our study areas. A number of conclusions may be extracted from our results:

\section{1. $\mathrm{OC} / \mathrm{EC} / \mathrm{WSOC}$ concentrations}

- OC concentrations at the sites did not show a dependence on the sampling region (Southern vs. Western Europe) but rather on local setting, i.e., the vicinity of local emission sources, with similar concentrations in Amsterdam and Barcelona and lower concentrations in Ghent. Urban topography and atmospheric dispersive conditions are probably the causes of the similar OC and EC concentrations registered in Amsterdam and Barcelona. In relative terms, the results indicate a larger influence of SOA in Ghent and a stronger traffic signal in Amsterdam and Barcelona.

- EC concentrations (much lower than OC) were highest in Barcelona and Amsterdam, with lower concentrations being registered in Ghent. The fact that a stronger traffic signal was not observed in Amsterdam is probably due to higher dispersive conditions at this Atlantic coastal site.

- Absolute WSOC concentrations were relatively similar at the three sites in the different seasons, and showed a dependence on meteorology (mainly precipitation).

\section{Sampling artefacts}

- Positive sampling artefacts ranged from $5-7 \%$ of the OC concentration in Ghent and 5-12\% in Amsterdam to $11-16 \%$ in Barcelona. Artefacts were most likely higher in Southern than in Western Europe, as a consequence of higher ambient temperatures. The impact of 
these artefacts on mean daily PM2.5 mass concentrations is, on average, only $1-3 \%$ and thus not significant with regard to EU daily or annual limit values, but it may be relevant for health-related issues.

3. Sources of carbonaceous aerosols

- Three types of episodes were defined for each site regarding the sources of carbonaceous aerosols: continental, Atlantic and local.

- In Western Europe, it was estimated that $68 \%$ of the OC concentration originated from longrange transport during continental episodes, while in Southern Europe only $44 \%$ resulted from non-local sources during such episodes.

\section{Acknowledgements}

The authors acknowledge the financial support provided by the Spanish Ministry of Education and Science (Secretaría de Estado de Educación y Universidades and Project CGL2004-05984_C0702/CLI), the Belgian Federal Science Policy Office and an Institutional Research Plan of the Institute of Analytical Chemistry of the Academy of Sciences of the Czech Republic (No. AV0 Z40310501) and by the Grant Agency of the Academy of Sciences of the Czech Republic under Grant no. A400310505. This study has been partially funded by the European Social Fund. Special thanks are due to Sheila Dunphy for performing the gravimetric measurements, and to Jan Cafmeyer, Peter Wallast and Gerard Kos for their help with the sampling setups in Ghent and Amsterdam. The authors are also indebted to the GGD Amsterdam for providing access to the air quality monitoring cabin, as well as to data from the Overtoom station. The authors gratefully acknowledge the NOAA Air Resources Laboratory (ARL) for the provision of the HYSPLIT transport and dispersion model used in this publication (http://www.arl.noaa.gov/ready/hysplit4.html).

\section{References}

Birch, M.E., Cary, R.A., 1996. Elemental carbon-based method for monitoring occupational exposures to particulate diesel exhaust. Aerosol Science and Technology 25, 221-241.

Draxler, R.R., Rolph, G.D., 2003. HYSPLIT (HYbrid SingleParticle Lagrangian Integrated Trajectory) Model access via NOAA ARL READY Website 〈http://www.arl.noaa.gov/ ready/hysplit4.html $>$.

EPA, 1994. Sampling carbonaceous aerosols: a review of methods and previous measurements. US-Environmental Protection Agency.
EU/1999/30 European Directive, 1999. Council Directive relating to limit values for sulphur dioxide, nitrogen dioxide and oxide of nitrogen, particulate matter and lead in ambient air. The Council of the European Union.

Kleefeld, S., Hoffer, A., Krivacsy, Z., Jennings, S.G., 2002. Importance of organic and black carbon in atmospheric aerosols at Mace Head, on the West Coast of Ireland $\left(53^{\circ} 19^{\prime} \mathrm{N}, 9^{\circ} 54^{\prime} \mathrm{W}\right)$. Atmospheric Environment 36, 4479-4490.

Mader, B.T., Flagan, R.C., Seinfeld, J.H., 2001. Sampling atmospheric carbonaceous aerosols using a particle trap impactor/denuder sampler. Environmental Science and Technology 35, 4857-4867.

Mader, B.T., Schauer, J.J., Seinfeld, J.H., Flagan, R.C., Yu, J.Z., Yang, H., Lim, H.J., Turpin, B.J., Deminter, J.T., Heidemann, G., Bae, M.S., Quinn, P., Bates, T., Eatough, D.J., Huebert, B.J., Bertram, T., Howell, S., 2003. Sampling methods used for the collection of particle-phase organic and elemental carbon during ACE-Asia. Atmospheric Environment 37, 1435-1449.

Maenhaut, W., Chi, X., Cafmeyer, J., Mikuška, P., Večeřa, Z., Broškovičová, A., 2003. Field investigations with a diffusion denuder for the elimination of sampling artifacts for carbonaceous aerosols. Journal of Aerosol Science, S1171-S1172 (Abstracts of the European Aerosol Conference 2003).

Maenhaut, W., Chi, X., Cafmeyer, J., Salma, I., Mikuška, P., Večeřa, Z., Broškovičová, A., 2004. Investigations during summer field campaigns in central Europe on the performance of a diffusion denuder for the elimination of sampling artifacts for carbonaceous aerosols. Journal of Aerosol Science, S1069-S1070 (Abstracts of the European Aerosol Conference 2004).

Maenhaut, W., Chi, X., Viana, M., Cafmeyer, J., Mikuška, P., Večeřa, Z., 2005. Investigations during summer field campaigns in Ghent and Barcelona on the performance of a diffusion denuder for the elimination of sampling artifacts for carbonaceous aerosols. In: Abstracts of the European Aerosol Conference 2005, 28 August-2 September 2005, Ghent, Belgium, Abstract no. 572.

Mikuška, P., Večeřa, Z., Broškovičová, A., Štěpán, M., Chi, X., Maenhaut, W., 2003. Development of a diffusion denuder for the elimination of sampling artifacts for carbonaceous aerosols. Journal of Aerosol Science, S761-S762 (Abstracts of the European Aerosol Conference 2003).

Nunes, T.V., Pio, C.A., 1993. Carbonaceous aerosols in industrial and coastal atmospheres. Atmospheric Environment 27A, 1339-1446.

Querol, X., Alastuey, A., Viana, M.M., Rodríguez, S., Artíñano, B., Salvador, P., Santos, S.G.D., Patier, R.F., Ruiz, C.R., Rosa, J.D.L., Campa, A.S.D.L., Menedez, M., Gil, J.I., 2004. Speciation and origin of PM10 and PM2.5 in Spain. Journal of Aerosol Science 35, 1151-1172.

Salma, I., Chi, X., Maenhaut, W., 2004. Elemental and organic carbon in urban canyon and background environments in Budapest, Hungary. Atmospheric Environment 38, 27-36.

Schmid, H., Laskus, L., Abraham, H.J., Baltensperger, U., Lavanchy, V., Bizjak, M., Burba, P., Cachier, H., Crow, D., Chow, J., Gnauk, T., Even, A., ten Brink, H.M., Giesen, K.P., Hitzenberger, R., Hueglin, C., Maenhaut, W., Pio, C., Carvalho, A., Putaud, J.P., Toom-Sauntry, D., Puxbaum, H., 2001. Results of the "carbon conference" international aerosol carbon round robin test stage I. Atmospheric Environment 35, 2111-2121. 
Sillanpää, M., Frey, A., Hillamo, R., Pennanen, A.S., Salonen, R.O., 2005. Organic, elemental and inorganic carbon in particulate matter of six urban environments in Europe. Atmospheric Chemistry and Physics 5, 1-11.

Turpin, B.J., Huntzicker, J.J., 1995. Identification of secondary organic aerosol episodes and quantisation of primary and secondary organic aerosol concentrations during SCAQS. Atmospheric Environment 29, 3527-3544.

Turpin, B.J., Saxena, P., Andrews, E., 2000. Measuring and simulating particulate organics in the atmosphere: problems and prospects. Atmospheric Environment 34, 2983-3013.

Viana, M., Chi, X., Maenhaut, W., Querol, X., Alastuey, A., Mikuška, P., Večeřa, Z., 2006a. Organic and elemental carbon concentrations during summer and winter sampling cam- paigns in Barcelona, Spain. Atmospheric Environment 40, 2180-2193.

Viana, M., Chi, X., Maenhaut, W., Cafmeyer, J., Querol, X., Alastuey, A., Mikuška, P., Večeřa, Z., 2006b. Influence of sampling artefacts on measured PM, OC and EC levels in carbonaceous aerosols in an urban area. Aerosol Science and Technology 40, 107-117.

WHO, 2003. Health aspects of air pollution with particulate matter, ozone and nitrogen dioxide. World Health Organization, 98 pp.

Zdráhal, Z., Oliveira, J., Vermeylen, R., Claeys, M., Maenhaut, W., 2002. Improved method for quantifying levoglucosan and related monosaccharide anhydrides in atmospheric aerosols and application to samples from urban and tropical locations. Environmental Science and Technology 36, 747-757. 